\title{
Carbohydrases of the bovine small intestine
}

\author{
By N. B. COOMBE* AND R. C. SIDDONS† \\ National Institute for Research in Dairying, Shinfield, Reading RG2 ${ }_{9} A T$
}

(Received ${ }_{3}$ October 1972 - Accepted 8 March 1973 )

\begin{abstract}
I. Homogenates of mucosa from bovine small intestine hydrolysed isomaltose slowly.
2. The enzyme exhibited maximum activity at $\mathrm{pH} 6 \cdot 0-6 \cdot 2$ and possessed a $K_{m}$ value of 9. I mM.

3. Isomaltase and maltase activities showed a similar pattern of distribution along the small intestine; activity was higher in the jejunum than in the ileum, the lowest activity being in the duodenum.

4. Neither activity changed markedly with age.

5. The disaccharidase activities (maltase, isomaltase, trehalase, lactase and cellobiase) of the small intestine were found in the sediment when homogenates were centrifuged at $100000 \mathrm{~g}$.

6. Heat inactivation studies suggested that there was one enzyme which hydrolysed trehalose, one enzyme which hydrolysed isomaltose, one enzyme which hydrolysed lactose and cellobiose and that the hydrolysis of maltose was brought about by more than one enzyme.
\end{abstract}

The complete breakdown of starch to glucose in the intestine requires enzymes capable of splitting both $\alpha-1,4-$ and $\alpha-1,6$-glycosidic linkages. The amylose fraction of starch is broken down by pancreatic amylase to maltotriose and maltose, which are further hydrolysed to glucose by the maltase activity of the small intestine. Pancreatic amylase, however, is inactive towards $\alpha$-1,6-glycosidic linkages (Semenza, I968) and therefore the complete hydrolysis of the amylopectin fraction of starch is dependent on the presence of an $\alpha-1,6$-glycosidase in the intestine. The enzyme responsible for the hydrolysis of $\alpha-\mathrm{I}, 6$-linkages in the small intestine is generally known as isomaltase since the disaccharide isomaltose [6-( $\alpha-\mathrm{D}$-glucopyranosyl)-D-glucose] has been used for measuring its activity. The same enzyme has been shown to hydrolyse palatinose (isomaltulose) [6-( $\alpha$-D-glycopyranosyl)-D-fructose] in man (Dahlqvist, Aurrichio, Semenza \& Prader, 1963) and in the pig (Dahlquist, 196r $a$ ).

In a previous study of the bovine intestinal disaccharidases (Siddons, I968) it was found that the calf differs from most other mammals in having no detectable sucrase activity and a maltase activity which does not increase with age. Furthermore, palatinose was not hydrolysed by homogenates of bovine intestinal mucosa, and it might be inferred that the calf is unable to hydrolyse $\alpha-1,6$-glycosidic linkages. However, since in other mammals the rate of palatinose hydrolysis is much slower than that of isomaltose, it was decided to study the ability of bovine small intestine to hydrolyse isomaltose and to investigate the multiplicity of the bovine small intestinal disaccharidases.

\footnotetext{
* Present address; Geriatric Medicine, Southampton General Hospital, Tremona Road, Southampton.

† Present address: Wellcome Trust Research Laboratories, PO Box 43640, Nairobi, Kenya.
} 
EXPERIMENTAL

Preparation of homogenates. The small intestines of young, milk-fed, bull calves (I-I 2 weeks old) and adult cows were removed and chilled in ice immediately after the animals had been slaughtered at the abattoir. Each intestine was divided into three sections: the duodenum, the jejunum and the ileum. A point half-way along the small intestine was taken arbitrarily as the junction of the jejunum and the ileum. Each section was slit open, washed in a solution of $0.15 \mathrm{M}-\mathrm{NaCl}$ and gently blotted with a piece of cloth. The mucosa was scraped off with a glass slide and a weighed amount (approx. $10 \mathrm{~g}$ ) was homogenized with three vol. chilled $0.15 \mathrm{M}-\mathrm{NaCl}$ in an homogenizer (Measuring and Scientific Equipment Ltd, Crawley, Sussex) at topspeed for $3 \mathrm{~min}$. The volume of the whole homogenate was then adjusted to $100 \mathrm{ml}$ with $0.15 \mathrm{M}-\mathrm{NaCl}$, and after thorough mixing was centrifuged at $600 \mathrm{~g}$ for $10 \mathrm{~min}$. The disaccharidase activities of the $600 \mathrm{~g}$ supernatant fraction were found to be between 98 and $100 \%$ of those of the whole homogenate, and as this supernatant fraction allowed more representative sampling it was used in all subsequent experiments and is referred to in the subsequent work as the homogenate.

Differential centrifugation. The homogenate was centrifuged at $7000 \mathrm{~g}$ for $20 \mathrm{~min}$ at $4^{\circ}$. The supernatant fraction was removed and centrifuged at $100000 \mathrm{~g}$ for $90 \mathrm{~min}$ at $4^{\circ}$. Both the $7000 \mathrm{~g}$ and the $100000 \mathrm{~g}$ sediment were washed with $0.15 \mathrm{M}-\mathrm{NaCl}$ and then resuspended in the volume of $0 \cdot 15 \mathrm{M}-\mathrm{NaCl}$ from which they were originally centrifuged.

Heat inactivation. Inactivation of the intestinal disaccharidases was carried out at $55^{\circ}, 60^{\circ}$ and $65^{\circ}$. A $5^{\circ} \circ \mathrm{ml} \mathrm{sample} \mathrm{of} \mathrm{homogenate} \mathrm{was} \mathrm{mixed} \mathrm{with} 5.0 \mathrm{ml} 0.2 \mathrm{M}$-sodium phosphate buffer, $\mathrm{pH} 7 \cdot 0$, in a thin-walled glass tube. The temperature of the mixture was raised quickly by immersing the tube in a water-bath maintained at a temperature $7-8^{\circ}$ higher than the temperature at which inactivation was being studied. The tube was shaken continuously and the desired temperature was reached within I min. The tube was then transferred to a water-bath maintained at the temperature being studied. Samples of $\mathrm{I}^{\circ} \mathrm{O} \mathrm{ml}$ were taken at the moment when the required temperature was reached (zero-time sample) and at intervals of 10 min thereafter, and transferred to tubes cooled in ice.

Disaccharidase activities. Disaccharidase activity was measured by the method of Dahlqvist (I964) using 28 mM-substrates made up in 50 mM-sodium maleate, $\mathrm{pH} 5 \cdot 6$ for lactase, cellobiase and trehalase and $\mathrm{pH}_{5} .8$ for palatinase, maltase and isomaltase. One unit of disaccharidase activity is defined as that which hydrolyses $\mathrm{I} \mu \mathrm{mol}$ disaccharide in I min at $37^{\circ}$ (one-sixtieth of the unit used by Siddons (1968) when reporting earlier results).

Determination of protein. The protein content of the samples was assayed by the method of Lowry, Rosebrough, Farr \& Randall (195 ${ }^{\mathrm{I}}$ ). A standard curve was prepared with bovine plasma albumin. 


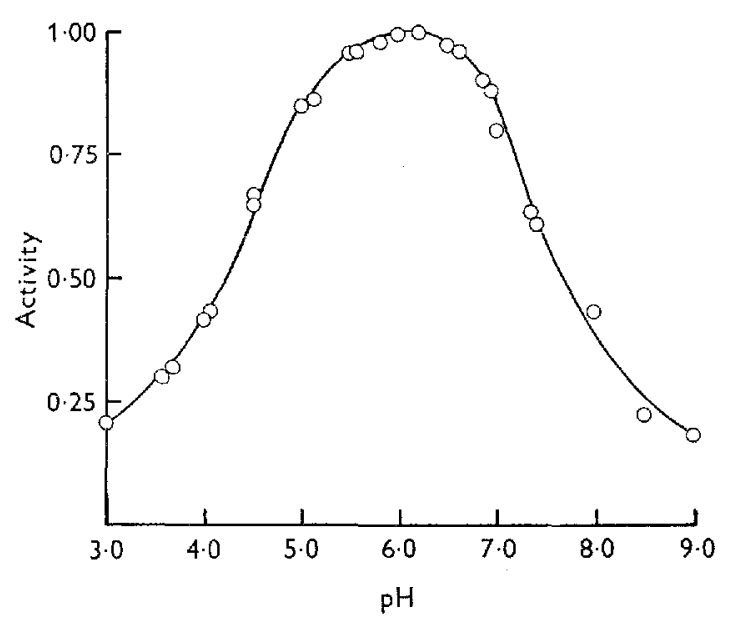

Fig. I. $\mathrm{pH}$ activity for the isomaltase activity of an homogenate of calf small intestinal mucosa. Enzyme activity is expressed relative to activity at optimum $\mathrm{pH}$. The buffers used were: $\mathrm{pH} 2.2-$ 3.4, 50 mM-glycine-HCl; $\mathrm{pH} \mathrm{3.6-5.4,} \mathrm{50} \mathrm{mM-sodium} \mathrm{acetate;} \mathrm{pH} 5.5-7.0$, 60 mm-sodium maleate; $\mathrm{pH} 6 \cdot 2-8 \cdot 0,50$ mM-sodium phosphate; $\mathrm{pH} 7 \cdot 5-9 \cdot 0,25$ mM-sodium veronal-IICl.

\section{RESULTS AND DISCUSSION}

Some properties of bovine small intestinal isomaltase activity

Effect of $p H$. The isomaltase activity in homogenates of calf jejunal mucosa was measured over a $\mathrm{pH}$ range of $3^{\cdot 0-9} \cdot{ }^{\circ}$ (Fig. I). The $\mathrm{pH}$ optimum was between $6 \cdot 0$ and $6 \cdot 2$.

Effect of substrate concentration. No substrate inhibition of isomaltase activity occurred up to $0.2 \mathrm{M}$ substrate concentration in contrast with the findings of Siddons (1968) with cellobiase. The $K_{m}$ for isomaltase as calculated by the method of Lineweaver \& Burk (I934) was found to be 9.1 mM.

Distribution along the small intestine. The results in Fig. 2 are the means of the activities for four young calves. In older calves the pattern of distribution remained the same. As Fig. 2 shows, homogenates of mucosa from all sections of the small intestine hydrolysed isomaltose. The isomaltase activity in the jejunum was slightly higher than that in the ileum, and the lowest activity was in the duodenum. The pattern of distribution was very similar to that found for maltase activity (see Fig. 2) and also similar to that described for isomaltase activity in other species, for example in man (Auricchio, Rubino, Tosi, Semenza, Landolt, Kistler \& Prader, I963), in the pig (Dahlqvist, 196r $b$ ) and in the rat (Doell \& Kretchmer, 1962).

The finding that homogenates of small intestinal mucosa of the calf hydrolysed isomaltose is of particular interest since in previous studies (Siddons, I968) it was found that homogenates of calf small intestinal mucosa did not hydrolyse palatinose and, in addition, in the present experiments no palatinase activity was detected in any section of the small intestine. In man (Dahlqvist et al. 1963) and in the pig (Dahlquist, 1961 $a$ ), isomaltose and palatinose have been shown to be hydrolysed by the same enzyme. 


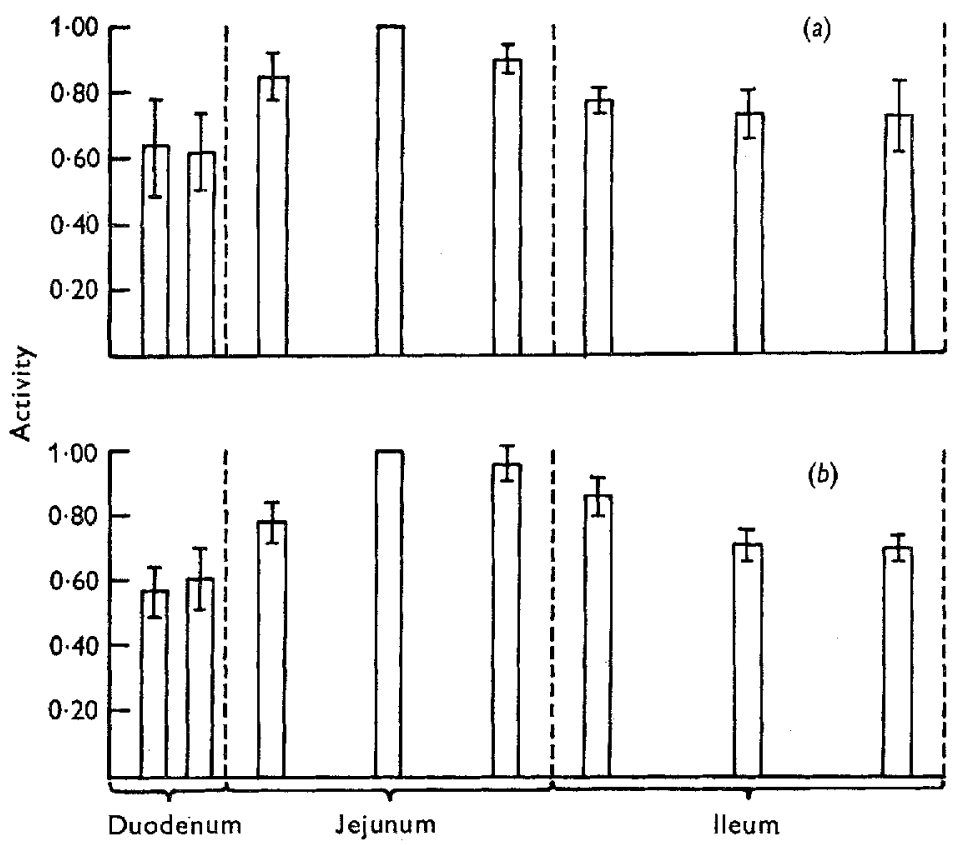

Fig. 2. Isomaltase (a) and maltase (b) activities of homogenates of mucosa from different parts of the small intestine of the calf. Enzyme activity is expressed rclative to activity of homogenate. Results are mean values with their standard errors for activities in four calves aged $7^{-14} \mathrm{~d}$. The length of the intestine was $\times 5 \cdot 25-19 \cdot 70 \mathrm{~m}$, that of the duodenum was $0.8 \rightarrow \mathrm{I} \cdot 4 \mathrm{~m}$. The activities are expressed as ratios of those in homogenates of mucosa from the middle of the jejunum.

\section{Table I. Maltase and isomaltase activities of homogenates of intestinal tissue from calves at different ages}

(Homogenates were prepared as described on p. 270)

\begin{tabular}{|c|c|c|c|c|c|c|c|}
\hline \multirow{3}{*}{$\begin{array}{l}\text { Age of } \\
\text { animals } \\
\text { (d) }\end{array}$} & \multirow{3}{*}{$\begin{array}{l}\text { Small intestine } \\
\text { length } \\
\text { (m) }\end{array}$} & \multicolumn{6}{|c|}{ Enzyme activity ( $\mathrm{mU} / \mathrm{mg}$ protein) } \\
\hline & & \multicolumn{3}{|c|}{ Maltase } & \multicolumn{3}{|c|}{ Isomaltase } \\
\hline & & $\begin{array}{l}\text { Proximal } \\
\text { duodenum }\end{array}$ & $\begin{array}{l}\text { Middle } \\
\text { jejunum }\end{array}$ & $\begin{array}{l}\text { Middle } \\
\text { ileum }\end{array}$ & $\begin{array}{l}\text { Proximal } \\
\text { duodenum }\end{array}$ & $\begin{array}{l}\text { Middle } \\
\text { jejunum }\end{array}$ & $\begin{array}{l}\text { Middle } \\
\text { ileum }\end{array}$ \\
\hline 7 & 16.49 & $2 \cdot 5$ & $3 \cdot 6$ & $2: 4$ & $1 \cdot 2$ & $\mathrm{I} \cdot 3$ & $\mathbf{I} \cdot 2$ \\
\hline 7 & $15 \cdot 25$ & $3 \cdot 2$ & $4 \cdot 4$ & $3 \cdot 6$ & $\mathrm{I} \cdot 4$ & $1 \cdot 7$ & $r \cdot 6$ \\
\hline 10 & $17 \cdot 10$ & $2 \cdot 8$ & $6 \cdot 9$ & $5 \cdot 0$ & $\mathrm{~T} \cdot 3$ & $3 \cdot 7$ & $2 \cdot 3$ \\
\hline 14 & 19.70 & $4 \cdot I$ & $6 \cdot 7$ & $5 \cdot 0$ & $2 \cdot 6$ & $3 \cdot 3$ & $2 \cdot 0$ \\
\hline $2 \mathrm{I}$ & $2 I \cdot 00$ & $3 \cdot 2$ & $7^{-6}$ & 47 & $I \cdot 5$ & $3 \cdot 7$ & $2 \cdot 7$ \\
\hline $5^{6}$ & $19 \cdot 75$ & $3 \cdot 2$ & $6 \cdot 8$ & $5 \cdot 7$ & $I \cdot 6$ & $3 \cdot 7$ & $I * 9$ \\
\hline 84 & $23 \cdot 30$ & $3 \cdot 3$ & $4 \cdot 9$ & $3 \cdot 7$ & $2 \cdot 0$ & $2 \cdot 5$ & $2 \cdot 0$ \\
\hline Adult & $42 \cdot 10$ & $4 \cdot 3$ & $4 \cdot 6$ & $4^{-I}$ & $I=2$ & $2 \cdot 3$ & $2 \cdot I$ \\
\hline & 43.55 & $5 \cdot I$ & $8 \cdot I$ & $5 \cdot 0$ & $I \cdot 7$ & $2 \cdot 8$ & $2 \cdot 6$ \\
\hline & $4 I \cdot 50$ & $3 \cdot 6$ & $5^{\circ} 0$ & $3-I$ & I.O & I. 6 & I. 4 \\
\hline
\end{tabular}


Table 2. Disaccharidase activities in the supernatant fraction and sediments after centrifugation of an homogenate of calf jejunal mucosa

(The preparation of the homogenate, supernatant fraction and sediments is described on p. 27o)

\begin{tabular}{|c|c|c|c|c|c|}
\hline \multirow[b]{2}{*}{ Fraction } & \multicolumn{5}{|c|}{ Enzyme activity $(\mathrm{mU} / \mathrm{ml})$} \\
\hline & Lactase & Cellobiase & Trehalase & Maltase & Isomaltase \\
\hline Homogenate & I I 54 & I 54 & 69 & 100 & 52 \\
\hline $7000 \mathrm{~g}$ supernatant & 777 & 100 & 53 & 84 & 46 \\
\hline $7000 \mathrm{~g}$ sediment & 418 & 56 & 52 & 14 & 6 \\
\hline Iooooog supernatant & 37 & 5 & Io & IO & 6 \\
\hline $100000 \mathrm{~g}$ sediment & 669 & 92 & 41 & 75 & 37 \\
\hline
\end{tabular}

Table 3. Solubilization of calf intestinal disaccharidases

(Homogenates, prepared as described on p. 270 , in $0.05 \mathrm{M}-\mathrm{Na}-\mathrm{K}$ phosphate buffer, pH 7.0 , were incubated for $3 \mathrm{~h}$ at $37^{\circ}$ with either $0.2 \mathrm{mg}$ trypsin/mg protein in homogenate, or $0.2 \mathrm{mg}$ papain $+0.5 \mathrm{mg}$ cysteine hydrochloride/mg protein in homogenate)

\begin{tabular}{|c|c|c|c|c|c|}
\hline & \multicolumn{5}{|c|}{ Enzyme activity $(\mathrm{mU} / \mathrm{ml})$} \\
\hline & Lactase & Cellobiase & Maltase & Isomaltase & 'Trehalase \\
\hline Untreated: homogenate & 1908 & 293 & IOI & 54 & $4 \mathrm{I}$ \\
\hline $\begin{array}{l}\text { Trypsin-treated: } \\
\text { Homogenate } \\
\text { I00000g supernatant } \\
\text { 100000g sediment }\end{array}$ & $\begin{array}{r}1773 \\
697 \\
1052\end{array}$ & $\begin{array}{r}252 \\
78 \\
160\end{array}$ & $\begin{array}{l}80 \\
70 \\
10\end{array}$ & $\begin{array}{l}50 \\
23 \\
27\end{array}$ & $\begin{array}{r}48 \\
6 \\
42\end{array}$ \\
\hline $\begin{array}{l}\text { Papain-treated: } \\
\text { Homogenate } \\
\text { I00000 } \mathrm{g} \text { supernatant } \\
\text { I } 00000 \mathrm{~g} \text { sediment }\end{array}$ & $\begin{array}{r}1737 \\
1640 \\
70\end{array}$ & $\begin{array}{r}250 \\
223 \\
33\end{array}$ & $\begin{array}{r}64 \\
57 \\
4\end{array}$ & $\begin{array}{r}33 \\
27 \\
4\end{array}$ & $\begin{array}{r}34 \\
25 \\
8\end{array}$ \\
\hline
\end{tabular}

Effect of age. Table I shows the isomaltase and maltase activities in the small intestines of animals of different ages. In many mammalian species the isomaltase and maltase activities have been found to increase during the weaning period (cf. Rubino, Zimbalatti \& Auricchio, I964). In the milk-fed calf, however, neither activity increased markedly with age and the activities in the intestines of all but the 7 -d-old calves were similar to those of adult animals. In all regions of the intestine and at all ages studied, the isomaltase activity was approximately $50 \%$ of the maltase activity under the conditions of assay used.

The similar distribution of isomaltase and maltase activities along the small intestine of the calf suggested that the same active site may be responsible for both activities. An attempt was therefore made to separate the two activities and study the relationships between them and other disaccharidases present.

\section{Cellular localization of disaccharidase activity}

Measurement of the disaccharidase activities in the sediments and supernatant fractions obtained by differential centrifugation of mucosal homogenates showed that most of the disaccharidase activity was located in particles that sedimented at $100000 \mathrm{~g}$ (Table 2). This finding is consistent with the view that the disaccharidases are 


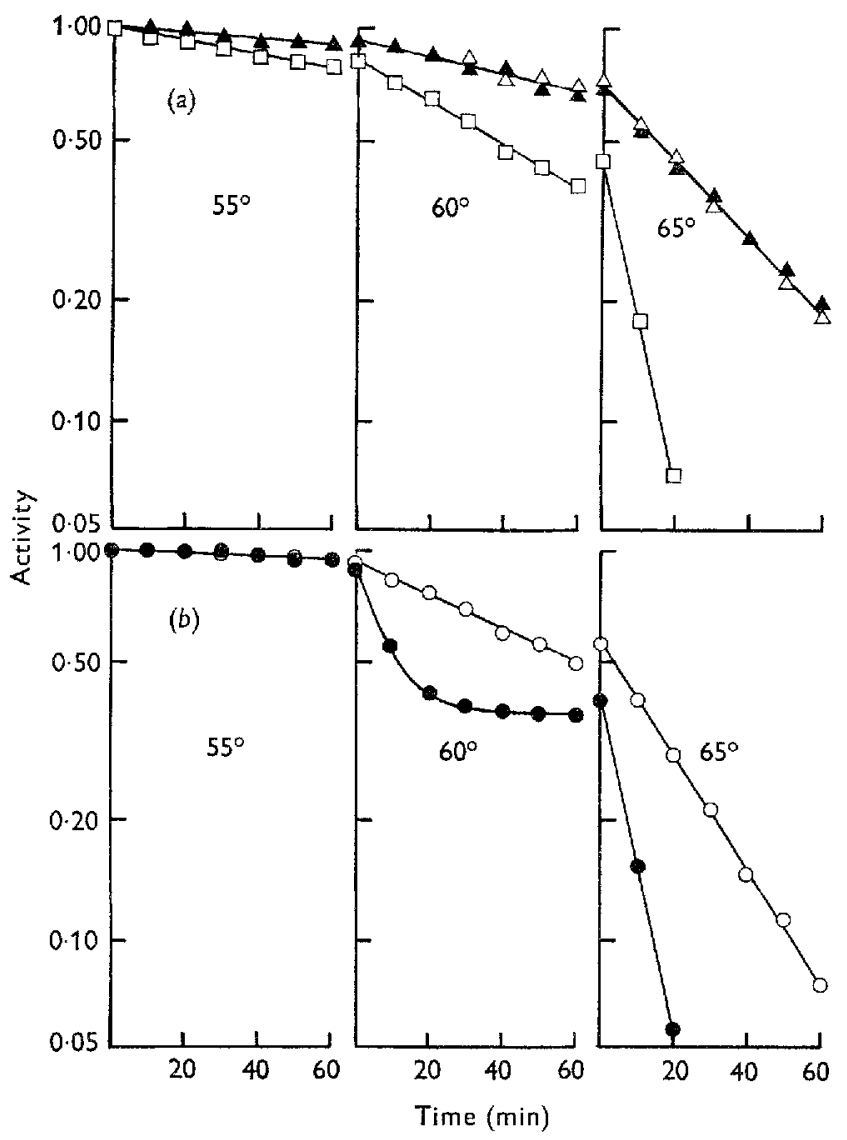

Fig. 3. Heat inactivation of $(a)$ the lactase $(\Delta)$, cellobiase $(\boldsymbol{\Delta})$ and trehalase $(\square)$ activities, and $(b)$ the isomaltase $(O)$ and maltase $(O)$ activities of an homogenate of calf jejunal mucosa at $55^{\circ}, 60^{\circ}$ and $65^{\circ}$. Remaining enzyme activity is expressed as a percentage of that of the unheated homogenate and plotted on a logarithmic scale.

contained in knobs, $6 \mathrm{~nm}$ in diameter, which are attached to, but not an integral part of the luminal membrane (Johnson, 1967 ). Thus the activities in the rooooo $\mathrm{g}$ sediment when expressed as a percentage of those in the homogenate, were $58,60,69,76$ and 70 for lactase, cellobiase, trehalase, maltase and isomaltase respectively. Attempts were made to solubilize the disaccharidases - that is to release the activity from the roo000 $\mathrm{g}$ sediment - by incubating the homogenate prepared in $0.05 \mathrm{M}-\mathrm{Na}-\mathrm{K}$ phosphate buffer, $\mathrm{pH} 7 \cdot 0$, with either trypsin $(0.2 \mathrm{mg} / \mathrm{mg}$ protein in homogenate) or papain $(0.2 \mathrm{mg}$ papain $+0.5 \mathrm{mg}$ cysteine hydrochloride/mg protein in homogenate). A greater loss of maltase, isomaltase and trehalase activities occurred during incubation with papain than during incubation with trypsin (Table 3). However, of the remaining activity, a higher percentage was released from the $100000 \mathrm{~g}$ sediment with papain than with trypsin. Thus, except for maltase and isomaltase, the disaccharidase activities of the $100000 \mathrm{~g}$ supernatant fraction obtained after papain treatment were much greater than those of the $100000 \mathrm{~g}$ supernatant fraction obtained with trypsin treatment. Auricchio, Dahlqvist \& Semenza (1963) have made similar observations, 
and they suggested that there is a species difference in the nature of the bonding joining the disaccharidases to the particles in which they are localized. Trypsin was found to solubilize the disaccharidases of the pig and the rat, but not those of man.

In all the homogenates, supernatant fractions and sediments, whether untreated, treated with trypsin or treated with papain, the ratio of lactase to cellobiase was always about 7 to $\mathrm{I}$, indicating that these two activities may be due to a single active site.

\section{Heat inactivation of the disaccharidase activities}

The heat inactivation of enzymes usually follows first-order kinetics and a linear relationship is therefore obtained when the logarithm of the remaining activity is plotted against time (White, Handler \& Smith, I968). This property of enzymes has been used extensively to separate intestinal disaccharidases, and although separation by this method is not necessarily conclusive the results of such experiments have been found to agree closely with results obtained by chromatography and electrophoresis (cf. Dahlquist, I960b).

The stabilities of the bovine intestinal disaccharidases were studied at $55^{\circ}, 60^{\circ}$ and $65^{\circ}$ (Fig. $3 a, b$ ). Trehalase activity was found to be the most heat-sensitive (Fig. $3 a$ ) and the kinetics of its inactivation indicate that this activity is due to a single enzyme not possessing any of the other disaccharidase activities tested. Similarly, trehalase was found to be a specific enzyme in the pig (Dahlqvist, 1960a). The inactivation curves for lactase and cellobiase activities coincided exactly (Fig. $3 a$ ), indicating that the hydrolysis of lactose and cellobiose is brought about by the same enzyme. This is in agreement with the results of chromatographic separations of disaccharidases from other species; for example, in man, no specific cellobiase activity could be detected and cellobiase activity was always associated with lactase activity (Semenza, Auricchio \& Rubino, I965).

A linear relationship was obtained between the logarithm of the remaining isomaltase activity and time (Fig. $3 b$ ), indicating that the hydrolysis of isomaltose is brought about by a single active site which has no action on the other disaccharides tested. The kinetics of maltase inactivation did not show a linear relationship (Fig. $3 b$ ) and suggest that at least two separate active sites contribute to the total maltase activity. One, constituting about $60 \%$ of the total maltase activity, is inactivated at $60^{\circ}$ and the other at $65^{\circ}$.

It has been suggested that the mammalian small intestinal disaccharidases are arranged into complexes, each containing one or more active sites (Eichholz, I966). From the results of Sephadex and ion-exchange chromatography, it appears that the $\alpha$-glucosidase activities (i.e. maltase, sucrase, isomaltase and palatinase) can be attributed to two such complexes. One, the maltase complex, contains one or more active sites - one in the pig (Dahlqvist, $1961 a$ ) and three in man (Auricchio, Semenza \& Rubino, 1965 ), all of which appear to be specific for maltose. The second, the sucrase-isomaltase complex, has two active sites: one which hydrolyses sucrose and maltose and another which hydrolyses isomaltose, palatinose and maltose. Such complexes have been isolated from the gut mucosa of the rabbit (Kolínská \& Semenza, 1967), the rat (Dahlquist, 1963) and man (Auricchio et al. 1965). In addition, it has been 
suggested by Semenza et al. (1965) that the sucrase-isomaltase complex in man is under the control of a single gene since certain human subjects who show sucrose malabsorption (an inborn error of metabolism) possess low maltase and isomaltase activities and no sucrase activity (Anderson, Messer, Townley, Freeman \& Robinson, I962; Auricchio, Rubino, Prader, Rey, Jos \& Frezal, I964; Gray, I97I). Siddons (1968) found no intestinal sucrase and palatinase activities in the calf and only a low maltase activity which did not increase with age. In these respects the enzyme activities in the calf resemble those in humans suffering from sucrose malabsorption, and it seems possible that the differences between the calf and most other mammals may all be related to the absence of a single sucrase-isomaltase complex. The isomaltase activity shown in the present study may thus have originated from a different enzyme or complex. Such a specific isomaltase activity, in addition to that associated with maltase activity, has been reported in the pig (Dahlquist, $1960 b$ ).

The authors thank Dr J. W. G. Porter and Dr R. H. Smith for their interest and advice.

\section{REFERENCES}

Anderson, C. M., Messer, M., Townley, R. R. W., Freeman, M. \& Robinsan, M. J. (I962). Lancet ii, $55^{6 .}$

Auricchio, S., Dahlqvist, A. \& Semenza, G. (1963). Biochim. biophys. Acta 73, 582.

Auricchio, S., Rubino, A., Prader, A., Rey, J., Jos, J. \& Frezal, J. (rg64). Lancet ii, 914.

Auricchio, S., Rubino, A., Tosi, R., Semenza, G., Landolt, M., Kistler, H. \& Prader, A. (1963). Enzymol. biol. clin. 3, r93.

Auricchio, S., Semenza, G. \& Rubino, A. (1965). Biochim. biophys. Acta 96, 498.

Dahlqvist, A. (1960a). Acta chem. scand. 14, 9.

Dahlqvist, A. (1960b). Acta chem. scand. 14. 72 .

Dahlqvist, A. (1961 a). Acta chem. scand. 15,808 .

Dahlqvist, A. (1961 $b$ ). Biochem. $\mathcal{F}, \mathbf{7 8}, 282$.

Dahlqvist, A. (1963). Biochem. $\mathcal{7} .86,72$.

Dahlquist, A. (1964). Analyt. Biochem. 7, 18.

Dahlquist, A., Auricchio, S., Semenza, G. \& Prader, A. (1963). F. clin. Invest. 42, 556.

Doell, R. G. \& Kretchmer, N. (1962). Biochim. biophys. Acta 62, 353.

Eichholz, A. (1966). Proc. Wid Congr. Gastroenterol. 11, Tokyo Vol. 2, p. 296 (Recent Advances in Gastroenterology).

Gray, G. M. (1971). A. Rev. Med. 22, 39 I.

Johnson, C. F. (1967). Science, N.Y. I55, 1670.

Kolínská, J. \& Semenza, G. (1967). Biochim. biophys. Acta 146, 181.

Lineweaver, H. \& Burk, D. (1934). F. Am. chem. Soc. 56, 658 .

Lowry, O. H., Rosebrough, N. J., Farr, A. L. \& Randall, R. J. (1951). F. biol. Chem. 193, 265.

Rubino, A., Zimbalatti, F. \& Auricchio, S. (1964). Biochim. biophys. Acta 92, $3 \circ 5$.

Semenza, G. (1968). In Handbook of Physiology Sect. 6 Alimentary Canal p. 2637 [C. F. Code, editor]. Washington, DC: American Physiological Society.

Semenza, G., Auricchio, S. \& Rubino, A. (1965). Biochim. biophys. Acta 96, 487 .

Siddons, R. C. (1968). Biochem. F. ro8, 839 .

White, A., Handler, P. \& Smith, E. L. (I 968). In Principles of Biochemistry $4^{\text {th }}$ ed., p. 234. London: McGraw-Hill. 